\title{
Entrepreneurship among Rural Women through CSR Initiatives
}

\author{
Nishu Kanwar Bhati* and Rajshree Upadhyay \\ Department of Extension and Communication, Management, College of Community and \\ Applied Sciences, MPUAT, Udaipur, Rajasthan, India \\ *Corresponding author
}

\section{A B S T R A C T}

\section{Keywords \\ Entrepreneurship, Corporate Social Responsibility, Rural women \\ Article Info \\ Accepted: \\ 16 August 2018 \\ Available Online: \\ 10 September 2018}

Rural women frequently have primary responsibility for agricultural production, in addition to domestic responsibilities and childcare. In developing country like India where economic status of women is very pathetic especially in rural areas and opportunities of earning are very less providing entrepreneurial training to be started into an enterprise have paved the way for economic independence of rural women. Corporate Social Responsibility (CSR) initiatives for women empowerment through entrepreneurship have been acting as one of the major tool towards promoting rural women to be economically independent. Many private companies have been working in this area, claiming to bring a significant change in the lives of rural women. Thus the present paper aims to study the entrepreneurship among rural women through CSR initiatives.

\section{Introduction}

Entrepreneurship is an innovative and dynamic process, whereby, a new enterprise is created. Entrepreneur is a catalytic agent of change, which generates employment opportunities for others. This is more beneficial for women in rural areas as it enable them to add to the family income while taking care of their farm, home and livestock centered tasks. Rural women possess abundant resources to take up an enterprise. Hence she can effectively undertake both production and processing oriented enterprises. Corporate Social Responsibility, CSR for most of the companies has revolved around communitybased development approach. Many have actively worked towards the economic and social empowerment of women. Some of them have promoted the formation of self-help groups which were supported to take up income generating activities after sufficient training and capacity building. It can be observed that there is an emphasis on women and their overall well-being and also a mention about gender equality and empowerment of women. It has been proved that extra income in the hands of women leads to significant and positive changes in human development since it is largely spent on children's education, health and nutrition, and is a catalyst for gendering development. Many corporate houses are working towards empowering women by improving income and employment for them in rural areas. Hindustan Zinc Limited (HZL) has been working 
towards empowering women since years. Various projects particularly for women empowerment have been carried out to impact he lives of rural women living near the plant areas. An attempt has been made in the present paper to study the sources of motivation, support given under CSR, reasons for taking up an entrepreneurial activity, income earned and contribution in family expenditure of the earned income by rural women after becoming the beneficiaries of Hindustan Zinc Limited (HZL).

\section{Materials and Methods}

The present study was conducted in the Udaipur district of Rajasthan, where HZL has its headquarters. For the purpose of the study 60 rural women beneficiaries of HZL's CSR initiatives were selected randomly. Data were collected using interview schedule and frequency, percentage and mean weighted score was used to analyze the data.

\section{Results and Discussion}

\section{Sources of motivation}

Motivation is necessary for mobilizing the rural women if any programme is to succeed. A motive is some inner drive, impulse or intention. Motivation is providing with a motive. It is a process of initiating a purposeful action. There are different sources which motivates a woman to start an enterprise. The response for different sources of motivation was measured on five point continuum of no, least, less, average and high assigning 0,1,2,3,4 scores. The MWS were ranked to highlight the important sources of motivation. The respondents ranked CSR perssonels (Rank I) as the most important source of motivation, followed by self (Rank II) and friends (Rank III). Probe into the matter revealed that the CSR personnels were very much active to instigate motivation in the beneficiaries to be the part of group enterprise. They reached the beneficiaries at personal level and explained the benefits of earning income and becoming economically empowered.

\section{Support given by CSR}

HZL worked with rural women beneficiaries by forming them into SHGs and imparting entrepreneurial training in stitching, embroidery, bag making etc. After completion of the training, the trainee group was given orders to stitch kurtas, pajamas, skirts and various apparels. They were linked to Centre for the study of Values (Cos-V), an NGO through which they sold the products and received payment on item basis. Respondents were asked to specify the support given to them under CSR initiatives. The data in Table 2 reveals that out of the total respondents who started their enterprise after receiving trainings all the respondents $(100 \%)$ reported time to time guidance and technical knowhow, establishment of market links, providing of raw material and upgrading and training of new skill as support received under CSR initiatives.

\section{Reason of starting an enterprise}

The response of the respondents regarding reasons to start an enterprise was again recorded on five point continuum as not important, least important, less important, important and most important. Perusal of the Table 4 indicates that to earn money for better living was the most preferred reason of starting an enterprise by the beneficiaries of HZL. To become economically independent was ranked II in order of preference followed by to save for the future (Rank III). Reasons like to come out of the four walls of the house and starting the enterprise under persuasion were lesser preferred reasons by the respondents. 
Table.1 Rankwise distribution of sources of motivation of the respondents

\begin{tabular}{|l|l|c|}
\hline $\begin{array}{l}\text { S. } \\
\text { No }\end{array}$ & Sources of motivation & Mean Weighted Scores \\
\hline 1 & Family member & HZL \\
\hline $\mathbf{2}$ & Relatives & V $(1.23)$ \\
\hline 3 & Friends & VI $(0.2)$ \\
\hline 4 & Neighbours & III $(2.53)$ \\
\hline 5 & CSR perssonel & IV $(1.63)$ \\
\hline 6 & Self & I $(3.88)$ \\
\hline
\end{tabular}

Table.2 Distribution of the respondents on the basis of support given by CSR

\begin{tabular}{|l|l|c|}
\hline S. No & Support given under CSR* & n $=106$ \\
\hline 1. & Guidance in technical know how & $60(100)$ \\
\hline 2. & Upgrading and training in new skills & $60(100)$ \\
\hline 3. & Establishment of market links & $60(100)$ \\
\hline 4. & Providing raw materials & $60(100)$ \\
\hline 5. & Establishment of financial linkage with banks & $0(0)$ \\
\hline 6. & Provision of funding through company & $0(0)$ \\
\hline 7. & Input support (Sewing machines, cattle) & $0(0)$ \\
\hline
\end{tabular}

*Multiple response

Table.3 Rankwise distribution of reason of starting an enterprise by the respondents

$\mathrm{n}=60$

\begin{tabular}{|l|l|c|}
\hline $\begin{array}{l}\text { S. } \\
\text { No }\end{array}$ & Reasons & Mean Weighted Scores \\
\hline $\mathbf{1}$ & To earn money for better living & HZL \\
\hline 2 & To learn new skill & I (3.92) \\
\hline 3 & To become economically independent & VII (2.18) \\
\hline 4 & To improve status in the family & V $(3.83)$ \\
\hline 5 & To earn respect from outsiders & IV $(2.93)$ \\
\hline 6 & To have better household assets & VI $(2.48)$ \\
\hline 7 & To come out of four walls of house & VIII (1.95) \\
\hline 8 & To save for future & III $(3.05)$ \\
\hline 9 & Under persuasion & IX $(0.43)$ \\
\hline
\end{tabular}


Table.4 Distribution of the respondents on the basis of monthly earnings from enterprise

\begin{tabular}{|l|l|c|}
\hline S. No & Monthly earnings (INR) & HZL f/\% \\
\hline 1. & $1000-3000$ & $0(0)$ \\
\hline 2. & $3001-5000$ & $11(18.33)$ \\
\hline 3. & $5001-7000$ & $13(21.66)$ \\
\hline 4. & $7001-9000$ & $13(21.66)$ \\
\hline 5. & $9001-11000$ & $17(28.33)$ \\
\hline 6. & $11001-13000$ & $4(6.66)$ \\
\hline 7. & $13001-15000$ & $2(3.33)$ \\
\hline
\end{tabular}

Table.5 Rankwise distribution of contribution in family expenditure by the respondents

\begin{tabular}{|l|l|c|}
\hline S. No & Aspects & Mean Weighted Scores \\
\hline 1 & Education & HZL \\
\hline 2 & Clothing & II $(1.58)$ \\
\hline 3 & Food & III $(1.48)$ \\
\hline 4 & Purchase of household assets & IV $(1.88)$ \\
\hline 5 & Purchase of productive assets & V $(0.27)$ \\
\hline 6 & Medical expenses & VI $(0.25)$ \\
\hline
\end{tabular}

$\mathrm{n}=60$

It can be inferred that reasons related to economic benefit acted as an impetus to start an enterprise. The findings are in conformity with Shukla and Dayal (2013) reported want of economic independence, and providing comfortable life to family members were the major sources of motivation by the respondents.

\section{Monthly earnings}

Before starting the enterprise the respondents reported not to earn any sort of income. But after becoming CSR beneficiaries nearly one third of the respondents $(28.33 \%)$ earned ₹ 9001- ₹ 1100 monthly. 21.66 per cent of the respondents reported to earn ₹ 5001-₹ 7000 and ₹ 7001-₹ 9000 alike. Few respondents $(3.33 \%)$ even reported to earn ₹ 13001₹ 15000 monthly, which was a big amount. Giving an assured market has helped the beneficiaries to continue with the enterprise and earn a regular income. Study by Sarmah and Das (2012) reported alike that women started some income generating activities after joining SHGs which helped in improving their incomes.

\section{Contribution in family expenditure}

Data pertaining to the contribution the respondents make in their respective family expenditure was tabulated in Table 4.30. The different aspects of expenditure were rated on three point continuum as no, to some extent and to great extent. The rankwise distribution of the MWS reveals that all the beneficiaries rank Food (Rank I) and Education (Rank II) as the important aspect where they spent the income earned followed by clothing ranked as III. Food and clothing are often considered as the basic essentiality of an individual, thus the respondents prioritize these aspects but it is also very encouraging to note that share of expenditure towards education is also increasing which shows the respondents zeal 
to provide a better future for their children. Similar results were reported by Yadava (2009) who reported that women utilized the money earned to fulfill their family requirement viz. food, clothing, health and maintenance of house. The CSR efforts by HZL have proven to be economically beneficial for the rural women. CSR personnels acted as true sources of motivation and helped them by giving guidance and technical know how, establishment of market links, providing of raw material and upgrading and training of new skill as and when required. Giving an assured market for their produce has helped them to earn on regular basis and which in turn has improved their economic status and their expenditure in important aspect like education beside basic necessities like food, shelter and clothing. The company's efforts on empowering women through making them economically independent is proving to be beneficially.

\section{References}

Sarmah, G. N. and Das, D. K. 2012. Micro Finance, Self Help Groups (SHGs) and The Socio Economic Development of Rural People (A Case Study With Special Reference to The Lakhimpur District Of Assam). Asian Journal of Research in Business Economics and Management. 2(4): 145- 159.

Shukla, C. and Dayal, R. 2013. Women Empowerment through Self Employment in Dairying Activities: Motivating Factors and Constraints. Journal of Community Mobilization and Sustainable Development. 8(1): 121128.

Yadava, R. 2009. Role of Swarnjayanti Gram Swarojgar Yojana in Promotion of Entrepreneurial Activities among Rural Women. M.Sc. Thesis submitted to MPUAT, Udaipur.

\section{How to cite this article:}

Nishu Kanwar Bhati and Rajshree Upadhyay. 2018. Entrepreneurship among Rural Women through CSR Initiatives. Int.J.Curr.Microbiol.App.Sci. 7(09): 2165-2169.

doi: https://doi.org/10.20546/ijcmas.2018.709.266 